XVI. Notes on the species of the families Lycidæ and Lampyridæ, contained in the Imperial Museum of Calcutta, with descriptions of new species, and a list of the species at present described from India. By the Rev. Henre S. Gorhan, F.Z.S., F.E.S.

[Read June 4th, 1890.]

The species of the family Telephoride contained in this collection have been noticed by me in the 'Proceedings' of the Zoological Society for 1889 [pt. ii., p. 96]. Of the two families of which this paper treats, species have been described by Mr. C. O. Waterhouse, M. E. Bourgeois, and myself from various parts of the East; and I have thought it would be useful if I gave a complete résumé of the Indian species, so far as they are at present known. That our knowledge of the coleopterous fauna of our Indian Empire is in many groups so very limited seems almost a reproach to us. It is much to the credit of the authorities of the Calcutta Museum that they have determined to inaugurate a better state of things.

In the following notes I have given the actual habitat of the specimens recorded, whenever I can ascertain it. The letters B. M. indicate that the species is contained in the British Museum; G., that the specimens referred to are in my own collection. Mus. Brus., Mus. Gen., refer to specimens contained in the Museums of Brussels and Genoa, sent to me for determination.

\title{
Group MALACODERMATA.
}

Family LYCIDÆ.

Gen. 1. Macrolycus, Waterhouse.

1. Macrolycus bowringii, Waterh. Allahabad (B. M.).

\section{Gen. 2. Calochromus, Guérin.}

1. Calochromus orbatus, Waterh.

Darjeeling (B. M., Mus. Calc., Dr. Anderson, đ̊?) ; Assam, Sibsaugor, Andaman Isles.

TRANS. ENT. SOC. LOND. 1890.-PART III. (SEPT.) 
The specimens with long antennæ appear to be females. This species, according to Mr. Waterhouse, occurs also in the Philippine Isles.

3. Calochromus apicalis, Hope.

Nepal (B. M.).

4. Calochromus rugatus, Waterh.

Allahabad (B. M.).

5. Calochromus ruber, Waterh.

Allahabad (B. M.), Madras (coll. G.), Singapore (G.).

6. Calochromus sp.

Very like $C$. ruber ; perhaps not distinct. Dibru (G.).

7. Calochromus velutinus, Waterh.

Burmah (B. M.).

8. Calochromus tarsalis, Waterh.

India (B. M.).

9. Calochromus sp.

India (G.).

A large species of similar size and appearance to M. bowringii.

Gen. 3. Lycostomus, Motschulsky.

1. Lycostomus similis, Hope.

Nepal, Allahabad, Siam, Ceylon, Bootan (B. M.) ; Sahibg., Sikkim, Naga Hills, Assam, Andaman Isles, S. India (Mus. Calc.).

2. Lycostomus thoracicus, Waterh.

Bootan, Sikkim, Darjeeling (B. M.); Cherra (Mus. Calc.).

3. Lycostomus sp.

Mount Kodeicanel (Castets).

Allied to L. thoracicus.

4. Lycostomus preustus, Fab.

Assam, Madras (Mus. Calc.). 
5. Lycostomus analis, Dalm.

Dacca, N. Bengal, Ceylon (B. M.).

Near L. preustus, and also allied to L. internexus, Walker, from Ceylon.

6. Lycostomus modestus, Waterh.

Bootan (B. M.), Kullu, Assam, Sibsaugor, Fista Valley (Mus. Calc.).

7. Iycostomus ambiguus, Waterh. Cachar (B. M.).

8. Lycostomus singularis, Waterh. S. India (B. M.).

9. Lycostomus rufiventris, Waterh.

Burmah (B. M.).

10. Lycostomus striatus, Waterh.

India.

India (G.).

11. Lycostomus sp.?.

Near debilis, Waterh., a Chinese species.

Gen. 4. Lyponia, Waterhouse.

1. Lyponia waterhousei, n. sp.

Niger, thorace subnitido, disco excepto, rufo angulis posticis rectis, elytris lateribus, apicem versus paululum latioribus; antennis corporis fere longitudine. Long. 12-14 mm., $\delta$ \& .

$H a b$. India (Mus. Calcutta, + Mus. Gorham).

The antennæ in this species are formed as in L. quadricollis, a Japanese species (of which a figure will be found in the Trans. Ent. Soc. Lond., 1883, t. 17, f. 5 and 6), excepting that those of the female are nearly of the same length as those of the male, and the fourth to the tenth joints are much more developed than in the female of $L$. quadricollis, being widely triangular, and becoming more acutely serrate as they approach the apex. The thorax is wider than in that species, the entire margin elevated, the anterior angles rounded, the sides a little contracted to the hind angles, but not so much so as to prevent those angles being right angles; the thorax is brick-red, with only the disk either infuscate or with a

TRANS. ENT, SOC. LOND, 1890,-PART III, (SEPT.) 20 
square pitchy-black patch; the elytra are pale brick-red, the costæ (nine in number) very even; the scutellum is black, rather long.

This insect is also allied to $L$. debilis, Waterh,, a species from China, but differs from it in not having the alternate costæ raised. It has long been known to me from a female specimen in my own collection : there are three male and one female specimens. Probably from the N. E. frontier, in the Calcutta Museum, and I have seen one in the British Museum.

\title{
2. Lyponia sp.?.
}

A single female specimen in the Mus. Calc., of a distinct species, smaller, with the thorax rufous only at the sides, and shorter and scarcely serrate antennæ.

Gen. 5. Plateros, Bourgeois.

1. Plateros dispellens, Walker.

South India, Ceylon (B. M.).

\section{Plateros languidus, C. Waterh.}

Ceylon (B. M.), Andaman Isles (Mus. Calc.).

\section{Plateros fuscicornis, n. sp.}

Pallide ochraceus, abdomine, antennis, tibiis, tarsisque fuscis prothorace oblongo-quadrato, disco utrinque foveolato. Long. 9-11 mm., 후 우.

Hab. Andaman Isles (Mus. Calc.).

The head, thorax, elytra, scutellum, femora, body beneath (except the abdomen), and the basal joint of the antennæ in part, are pale ochraceous yellow. The striæ of the elytra are quite even, and the very short scaly pubescence almost conceals the punctures. The thorax is shining: in addition to the rather deep but wide channel there is a transverse impression behind the frontal carina, and a very distinct, round, almost punctiform, fovea on each side. The legs are rather indeterminate in colour, being yellow at the base, and become fuscous at the tarsi.

Several specimens.

This is very near $P$. languidus, but much larger.

\author{
4. Plateros fuscipennis, Waterh. \\ Sylhet (B. M.).
}


5. Plateros carbonarins, Waterhouse.

Gen. 6. Xylobanus, Waterhouse.

1. Xylobanus gratiosus, Waterhouse.

Andaman Isles (Mus. Calc., B. M.).

Varies a good deal in size and somewhat in colour; two examples in my own collection are broader and redder than those in the Calcutta Museum.

Gen. 7. Metriorrhynchus, Guérin.

1. Metriorrhynchus sericeus, Waterhouse.

India (coll. Gorham), Sumatra (Leyden), Java (B. M.). Var. apice infuscato. India (B. M.).

2. Metriorrhynchus sericans, Waterhouse.

India (B. M.).

3. Metriorrhynchus lineatus, Hope, in Gray, Zool. Misc.

India, Nepal (B. M.), Sikkim (Mus. Calc.), Coimbator (B. M.).

Var. A, Waterhouse. Allahabad (B. M.).

Var. B. Ceylon.

4. Metriorrhynchus rubicundus, Waterhouse. Sylhet (B. M.).

Gen. 8. Conderis, Waterhouse.

1. Conderis signicollis, Waterhouse?.

Assam, Sibsaugor (Mus. Calc.).

Gen. 9. - - ?.

A single example of a species of a genus allied to Metriorrhynchus, but having but a single cell in the centre of the disk of the thorax.

Andaman Isles.

Gen. 10. Eros, Newman.

1. Eros sp.?.

A single specimen. India. 
Gen. 11. — ?

Allied to Plateros, but with pectinate antennæ in the male.

$$
\text { 1. - sp. }
$$

Of the size and in colour like $P$. languidus. Luteous, with the antennæ, tibiæ, tarsi, and elytra infuscate.

Andaman Isles.

Family LAMPYRID $Æ$.

Gen. 1. Vesta, Laporte.

1. Vesta saturnalis, Gorham, Trans. Ent. Soc. Lond., 1880, p. 13.

Naga Hills, 5000 ft. alt., Khasia Hills (Mus. G.) ; Sikkim, Sibsaugor in Assam (Mus. Calc.).

Gen. 2. Alecton, Laporte (cf. Pyrocœlia).

Genus 3. Lamprophorus, Gemminger \& Harold.

1. Lamprophorus tenebrosus, Walker.

India (G.), Pondicherry (Mus. Brus., G.), Ceylon (B. M.).

2. Lamprophorus crassus, Gorham, Trans. Ent. Soc. Lond. 1880, p. 88.

Pondicherry (Mus. Brus.).

3. Lamprophorus nepalensis, Gray, Zool. Misc., p. 26. Nepal (B. M.) ; Sikkim, Khasia Hills (Mus. Calc.) ; Assam Plains (G.).

Ceylon.

4. Lamprophorus diffinis, Walker.

Burmah.

5. Lamprophorus minor, Olivier.

Gen. 4. Diaphanes, Motschulsky.

1. Diaphanes indicus, Mots., Et. Ent., iii., 15.

India (Mus. Brus.) ; Assam, Sibsaugor (Mus. Calc.).

2. Diaphanes limbatus, Gorham, Trans. Ent. Soc. India (G.).

$$
\text { Lond., 1880, p. } 90 .
$$




\section{Diaphanes planus, n. sp.}

Pallide ochraceus; corpore subtus, antennis, pedibus alisque fuscis. Long. $17 \mathrm{~mm} ., \sigma^{\jmath}$.

Hab. India ?, Dr. J. Anderson (Mus. Calc.).

Of the same size, colour, and general appearance as Pyrocolia bicolor, Fab.; the thorax, however, is longer and more evenly rounded in front, and possesses the usual diaphanous area; the front margin is gently and evenly elevated, the sides less so. The hind margin is concave (as usual in this genus), so that the hind angles seem a little produced. The centre of the disc is very finely carinate.

Two specimens.

4. Diaphanes guttatus, Gorham, Trans. Ent. Soc. Lond., 1880, p. 90.

Bengal (Mus. Brus.).

Gen. 5. Phenopyrus, E. Olivier.

1. Phœnopyrus birmanensis, Olivier, Ann. Mus. Civ. de Genes., p. 347, 1885, t. 5, f. 1.

Burmah, Minhla (Mus. Gen.).

I have not seen this.

Gen. 6. Pyrocelia, Gorham.

1. Pyrocoelia foochowensis, Gorham, Trans. Ent. Soc. Lond., 1880, p. 93.

China, Foochow (G., B. M.) ; Burmah, Minhla (Mus. Gen. sec. E. Olivier).

2. Pyrocclia terminata, Gorham, Trans. Ent. Soc.

$$
\text { Lond., 1880, p. } 92 .
$$

India (G.), Sumatra (Mus. Gen. sec. E. Olivier).

3. Pyrocœlia lateralis, Gorham, Trans. Ent. Soc. Lond., 1880, p. 92.

Ceylon (G.), Java (Mus. Leyden), Sumatra (Mus. Gen. sec. E. Olivier).

4. [Pyrocolia plagiata, Gorham, l.c., p. 93.] Java (Mus. Leyden, E. Olivier, R. Oberthür). The occurrence of this in India needs confirmation. 
5. [Pyrocolia fumigata, Gorham, l.c., p. 93.] Malacca, Siam (G.), Sumatra (Mus. Leyden), Johore, Motiram (Mus. Calc.).

7. Pyrocolia lacordairei, E. Olivier, Rev. d'Ent., 1883, p. 327. Notes from the Leyden Mus., 1886.

Alecton indicus, Chev., in litt. Lac. Gen. Atlas. Bengal.

M. E. Olivier has shown that this is not congeneric with Alecton discoidalis, as might have been anticipated, seeing that is a Cuban insect, but that it is a Pyrocoelia. The species of this latter genus appear to have a very extended distribution in the East.

\section{Gen. 7. Luciola, Laporte.}

1. Luciola vespertina, Fab., Syst. Et., ii., p. 103; Gorham, Trans. Ent. Soc. Lond., 1880, p. 100; E. Olivier, Ann. Mus. Civ. de Gen., p. 359, 1885 (L. chinensis, L.).

India, Assam (G.), Sibsaugor (Mus. Calc.), Tenasserim (Mus. Calc.).

2. Luciola substriata, Gorham, Trans. Ent. Soc. Lond., 1880 , p. 100.

S. India, Madras, Bombay, Bengal (Mus. Brus.); Borneo, Java (Mus. Leyden); Ceylon (Mus. Gen. sec. E. Olivier).

M. Olivier does not agree with me in separating this. I remark, however, that as all the specimens he had seen, and which all appear to come from Ceylon, are of one type, he can hardly have seen the larger wide forms from Northern India, \&c. ; and I still think it will prove to be a valid distinction.

3. Luciola gorhami, Ritsema, Notes from Mus. Leyden,

$$
\text { v., p. } 4 .
$$

Luciola affinis, Gorh., l. c., p. 101, nec Ritsema.

Madras, Bombay, Bengal (Mus. Brus.); Calcutta (Mus. Calc.). 
4. Luciola malacce, Gorham, Trans. Ent. Soc. Lond., 1880, p. 101.

India, Madras (G.).; Malacca.

5. Luciola semilimbata, E. Olivier, Rev. d'Ent., 1883, India. ii., 75 .

Unknown to me.

6. Luciola ovalis, Hope, in Gray's Zool. Mise., 1831.

Luciola circumdata, Mots., Et. Ent., 1854, p. 50.

India (Hudd, G.), Assam (Mus. Brus., B. M.), Sibsaugor (Mus. Calc.), Burmah, Minhla (Mus. Gen. sec. E. Oliv.), Sumatra (Mus. Leyden).

This curious and distinct species was well described by Hope.

7. Luciola indica, Mots., Etud. Ent., iii., p. 53.

India (G.), Bombay (Mus. Brus.), Andaman Isles (G.).

8. Luciola xanthura, Gorham, Trans. Ent. Soc. Lond., 1880, p. 103.

India, Neilgherry Hills (Mus. Brus.).

9. Luciola insularis, E. Olivier, Rev. d'Ent., ii., p. 328.

Andaman Isles (Mus. Calc.).

I have identified a species, of which there are several specimens in the Calcutta Museum, with this, but with a good deal of doubt.

10. Luciola sp. ?.

Assam, Sibsaugor (Mus. Calc.).

Two specimens of a Luciola, with fuscous elytra narrowly margined and the disc of the thorax infuscate, cannot at present be determined.

11. Luciola testacea, Mots., Etud. Ent., 1854, p. 48 ;

E. Olivier, Ann. Mus. Civ. de Genes., 1885, p. 357.

M. Ernest Olivier has identified a species from Borneo, Sarawak, with this. Motschulsky's description is vague, as his also his 'Indes Orientales.' 
550 Notes on the families Lycidae and Lampyrida.

Gen. 8. Dioptoma, Pascoe.

1. Dioptoma adamsi, Pasc., Journ. of Ent., 1860, p. 118 , t. 5 , f. 2.

India, Madras (G.) ; Dacca.

Gen. 9. Оснотуra, Pascoe.

1. Ochotyra semiusta, Pase., l.c., 1862, p. 323, t. 16, f. 7. India, Malabar (Pascoe); China, Foochow (G.). 


\section{$2 \mathrm{BHL}$ Biodiversity Heritage Library}

Gorham, Henry Stephen. 1890. "XVI. Notes on the species of the families Lycidæand Lampyridæ, contained in the Imperial Museum of Calcutta, with descriptions of new species, and a list of the species at present described from India." Transactions of the Entomological Society of London 38, 541-550. https://doi.org/10.1111/j.1365-2311.1890.tb02707.x.

View This Item Online: $\underline{\text { https://www.biodiversitylibrary.org/item/50993 }}$

DOI: https://doi.org/10.1111/j.1365-2311.1890.tb02707.x

Permalink: https://www.biodiversitylibrary.org/partpdf/35934

\section{Holding Institution}

Smithsonian Libraries

\section{Sponsored by}

Smithsonian

\section{Copyright \& Reuse}

Copyright Status: Public domain. The BHL considers that this work is no longer under copyright protection.

This document was created from content at the Biodiversity Heritage Library, the world's largest open access digital library for biodiversity literature and archives. Visit BHL at https://www.biodiversitylibrary.org. 